\title{
Organ and tissue donation: use of quality tool for process optimization
}

\author{
Doação de órgão e tecidos: utilização de ferramenta de qualidade para a otimização do processo \\ Donación de órganos y tejidos: utilización de herramienta de calidad para la optimización del proceso
}

\author{
Neide da Silva Knihs ${ }^{1}$ (10) \\ Aline Lima Pestana Magalhães ${ }^{1(1)}$ \\ Juliana Santos ${ }^{1}$ (i⿱一) \\ Isabela dos Santos Wolter ${ }^{10}$ \\ Sibele Maria Schuantes Paim ${ }^{1}$
}

1. Universidade Federal de Santa Catarina. Departamento de Enfermagem. Florianópolis, SC, Brasil
Corresponding author:

Neide da Silva Knihs

E-mail: neide.knihs@ufsc.br

Submitted on 03/21/2019.

Accepted on 07/10/2019.

DOI: 10.1590/2177-9465-EAN-2019-0084

\section{Abstract}

Objective: Identify by means of a management tool causes of losses of possible and potential organs and tissues donation as opportunities of improvements in the organs and tissues donation system. Method: Descriptive and quantitative study developed in three hospitals in the south of the country, which used an instrument of the National Transplant Organization of Spain to trace opportunities of improvements in the scenario of the organs and tissues donation. Tha data collect was carried out in patients'medical records from July and October 2017. The data were analyzed through the descriptive statistics. Results: O the 321 deaths occurred, $73 \%$ were heart arrested and $27 \%$ were brain death. In all hospitals the percentage of brain death was higher than $25 \%$. The causes of losses involve hemodynamic alterations $78.3 \%$ and medical contraindications $21,7 \%$, with respect to hemodynamic instability $33 \%$ related to the hypotension, polyuria $28 \%$, sodium more than $155 \mathrm{mEq} / \mathrm{l} 22 \%$ and temperature below $35.5^{\circ} \mathrm{C}$ in $17 \%$. Conclusion and Implications for practice: The main causes of loss involve the hemodynamic instability and the contraindication, with respect to opportunities of improvements it was possible to measure the causes of the non-validation of the potential organs donor. The management tool used in the study allows the healthcare team to develop strategies directed towards actual problems incurred at the stages of the donation and transplantation process.

Keywords: Transplantation; Tissue and Organ Procurement; Health Management; Nursing; Health Status Indicators.

\section{Resumo}

Objetivo: Identificar por meio de uma ferramenta de gestão causas de perdas de possíveis e potenciais doadores de órgãos e tecidos como oportunidades de melhorias no sistema de doação de órgãos e tecidos. Método: Estudo quantitativo, descritivo, desenvolvido em três hospitais no Sul do País, o qual utilizou um instrumento da Organização Nacional de Transplantes da Espanha para rastrear oportunidades de melhorias no cenário da doação de órgãos e tecidos. A coleta de dados foi realizada em prontuários de pacientes entre julho e outubro de 2017. Os dados foram analisados por meio da estatística descritiva. Resultados: Das 321 mortes ocorridas, $73 \%$ eram de coração parado e $27 \%$ de morte encefálica. Em todos os hospitais a porcentagem de morte encefálica foi superior a $25 \%$. As causas das perdas envolvem alterações hemodinâmicas $78,3 \%$ e contraindicações médicas $21,7 \%$, quanto a instabilidade hemodinâmica $33 \%$ relacionadas a hipotensão, poliúria $28 \%$, sódio superior a $155 \mathrm{mEq} / \mathrm{l} 22 \%$ e temperatura inferior a $35,5^{\circ} \mathrm{C}$ em $17 \%$. Conclusão e Implicações para a prática: As principais causas de perda envolvem a instabilidade hemodinânica e a contraindicação, no que se refere as oportunidades de melhorias foi possível mensurar as principais causas da não validação do potencial doador de órgãos. A ferramenta de gestão utilizada no estudo permite a equipe de saúde desenvolver estratégias direcionadas a problemas reais ocasionados nas etapas do processo de doação e transplante.

Palavras-chave: Transplante; Obtenção de Tecidos e Órgãos; Gestão em Saúde; Enfermagem; Indicadores de Saúde.

\section{Resumen}

Objetivo: Identificar por medio de una herramienta de gestión causas de pérdidas de posibles y potenciales donantes de órganos y tejidos como oportunidades de mejorías en el sistema de donación de órganos y tejidos. Método: Estudio cuantitativo, descriptivo, desarrollado en tres hospitales en el sul del País, el cual utilizó un instrumento de la Organización Naciona de Trasplantes de España para rastrear oportunidades de mejorias en el escenario de la donación de órganos y tejidos. La recolección de datos fue realizada en historial clínico de pacientes entre julio y octubre de 2017. Los datos fueron analizados por medio de la estadística descriptiva. Resultados: De las 321 muertes ocurridas, $73 \%$ eran de corazón parado y $27 \%$ de muertes encefálica. En todos los hospitales el porcentaje de muertes encefálica fue superior a 25\%. Las causas de las pérdidas incluyen alteraciones hemodinámicas $78,3 \%$ y contraindicaciones de carácter médico $21,7 \%$, cuando la instabilidad hemodinámica $33 \%$ relacionadas con la hipotensión, poliuria $28 \%$, sodio superior a $155 \mathrm{mEq} / \mathrm{l} 22 \%$ y temperatura inferior a $35,5^{\circ} \mathrm{C}$ en $17 \%$. Conclusión y Implicaciones para la práctica: Las principales causas de la pérdida incluyen la instabilidad hemodinánica y la contraindicación, en el que se refiere a las oportunidades de mejorías ha podido ser medido la real, las principales causas de la no validación del potencial donante de órganos. La herramienta de gestión utilizada en el estudio permite a el equipo de salud desarrollar estrategias dirigidas a problemas reales ocasionados en las etapas del proceso de donación y trasplante.

Palabras clave: Transplante; Obtención de Tejidos y Órganos; Gestión en Salud; Enfermería; Indicadores de Salud. 


\section{INTRODUCTION}

The organs and tissues donation in Brazil and in the world has been significantly increasing. The number of effective donations has been increasing year by year, enabling patients who are awaiting for a transplant to stay a less waiting list time..$^{1-5}$

In our country, different improvement actions has been developed by governmental and non-governmental managers over the last ten years. These actions are directed towards the permancent education together with the health professionals, effectiveness strategies and agility in the logistics of the organs and tissues capture and implant, as well as in raising the awareness of the population for providing further clarifications to the society about the process of donation. ${ }^{1-2}$ All these improvements have been valuable, enabling Brazil to emerge from a rate of 7.2 effective donors per million population (pmp) in 2008 to $16.9 \mathrm{pmp}$ in 2018 , an increase of more than $150 \%$ over ten years. ${ }^{1-2}$

The statistics show effective improvements in this process and reveal that, there is still space and opportunity for ongoing progress and advances in this thematic, since there was an improvement in the number of effective donors over the years. However, losses related to underreporting of potential donors to the State Central Transplantation-SCTs and losses due to family refusals still persist with high rates. In 2018, approximately, 4,000 patients according to Brain Death criteria (BD) ceased being identified and, consequently, were not notified as potential donors to SCTs in Brazil. In that same year, 4,250 families refused to provide the organs and tissues donation of their relative. ${ }^{1}$

Spain, country with the best worldwide results, maintains an average annual donor loss rate, of approximately, $12.5 \mathrm{pmp} .^{1,6-7}$ The improvement of these results is directed to the strategies implemented, among the most effective, the permanent education of the health team and the quality assurance programme. ${ }^{6-7}$ The above programme uses tools management, which allows identifying opportunities for improvements in the donation scenario. ${ }^{6}$ Study carried out in Germany shows an increase in the effective donors rates after having been implanted the Spanish model in the donation process. ${ }^{8}$ Study developed in Belgium reveals improvements in the effective donors rates and brings recommendations for ongoing improvements in the process, in the donations results monitoring, in educational and training programms for donors detection .9

In this perspective of improvements in the scenario of the organs donation, one of the tools used in the Spanish model is called tool to screen and chart possible donors. He helps the healthcare team in identifying patients who have ceased to be notified to the SCTs, in addition to presenting the actual causes of non-notification of these patients. Through this tool, the Hospital Transplant Committee (HTC) could verify opportunities for improvements in the stages of the organs and tissues donation process and, then, create strategies to prevent losses of potential donors.

The nurse as a manager and assistential member of the HTC has been assuming the role of managing and supervising constant improvements in the stages of the donor process. Considered the professional with the greatest ability to go through the different knowledge areas, in this scenario, specially by the capacity to interact with the multiprofessional team, family, patient and health manager and for managing, prioritizing and making decisions soon enough. In addition, this professional has been assumed the results management and the effectiveness of this process, with the aim at minimizing eventual errors and damages that may occurr in the donation process. ${ }^{10-16}$

In Brazil, the nurse assumes the role of a member and manager of the HTC, besides developing actions related to identify, validate and manager the care to the possible donor (patient with clinical, laboratorial and radiological criteria for opening the brain death protocol), regarding the potential donor (patient whose BD protocol was concluded with positive result for BD) ${ }^{17}$ and the family. She supports and coordinates the logistics of capturing organs and administrative processes regarding the quality of this process. ${ }^{11-12,17}$

The nurse as manager of the HTC, together with the multiprofessional team of the Intensive Care Units (ICU's), has the great challenge of identifying, often, opportunities of improvements in the donation system and transplant to allow legal stages through legal and ethical parameters and above all, to ensure the safety and quality in the donation, besides feasible organs for the transplant. ${ }^{10-15}$ Screening opportunities of improvements in the health system provides the elaboration of effective strategies based on actual problems. The organs and tissues donation system is a complex process, thus, it requires a look of the health team targeted to licit stages, effective and safe in order to ensure quality in the donation and safety in the transplant.

In this context, the study brings the following leading question: The identification of the causes of losses of possible and potential donors of organs and tissues through a management tool can help the health team to propose strategies of improvements in the organs and tissues donation system?

Given this scenario, the study seeks to identify by means a management tool the causes of losses of possible and potential donors of organs and tissues as opportunities in the organs and tissues donation system.

\section{METHOD}

Quantitative, cross-sectional and descriptive study, in which we used a management tool of the Quality Assurance Programme of the Spanish National Transplant Organization (ONT, Spain), which was produced, having as theoretical referential Avedis Donabedian, having been translated, adapted and validated for Brazil. ${ }^{6}$

The management tool used in this study is called "tool to screen and chart possible donors", which has as proposal to present opportunities of improvement by means of the identification of possible donors non-notified to SCT. In Brazil, possible donor is defined as patients with clinical criteria to initiate the BD diagnosis; as a potential organs and tissues donor. Patients with diagnosis of BD concluded and notified to SCTs. ${ }^{17-18}$ 
The tool for screening and charting possible donors ${ }^{6}$ consists of the following items in its format: Data of the patient's profile; Information at the time of the hospitalization (causes of the hospitalization in the unit of critical patient; presence or not of neurological lesion; value of the Glasgow Coma Scale (GCS); presence of polyuria; type of pupil); Last information before the death (value of the Glasgow Coma Scale (GCS); presence of intracranial pressure; presence of polyuria; type of pupil; presence of sedation; presence of reflexes in the cerebral trunk; coughing reflex present; causes of coma); BD Protocol initiated; if there was or not the notification of the BD protocol to SCTs; and the death cause recorded in the death certificate.

The tool for screening and charting possible donors was used in three reference hospitals in neurosurgery and highlights in the notification of potential donors to SCTs in the south of the country. The choice of the three institutions took into account the fact that they meet a great demand of neurosurgical patients, with escolha pelas três instituições levou em consideração o fato de atenderem a uma grande demanda de pacientes neurocirúrgicos, with an average of 54 notifications of potential donors ( $\mathrm{pmp}$ ) per year to SCTs in each institution.

The data collect occurred in medical records of patients who died in the ICU's by nurses members of the HCT of the three hospitals, with the aid of the researchers. The instrument of the management tool was fulfilled for all the deaths occurred in the ICU's, between May and October 2017. The average time used by the nurses to collect the information was 10 minutes. The collect of information becomes fast, since the requested data are found in the first and in the last evolution of the multiprofessional team and were collected by the nurses in the following of the death confirmation. Given that not all the patients had neurological lesion, some instruments were not filled with all the information.

With regard to the inclusion criteria: all the medical records of patients who died in the UCl's during the period established have been part of the sample. Medical records with inelegible information, erased or with lack of information were excluded.

For analysis, the data were inserted in the Excel for Windows ${ }^{\circledR}$ 2003 programme and, next, relative frequencies (porcentages), absolute frequencies ( $n$ ) and average were calculated. The data were presented in the form of chart and graphics.

The study was approrved by the Research Ethics Committed of the Federal University of Santa Catarina (UFSC) under the protocol No. 1.410.164/16.

\section{RESULTS}

We evaluated 332 medical records, of which 11 were excluded due to no information is readable. In this way, 321 instruments were fulfiled to screen and chart possible donnors. The greatest number of fulfiled instrument was in the Hospital 1, 38.6\% (n 124 ), followed by the Hospital 3 with $32.7 \%$ (n 105), representing, thus, the hospitals with the greatest number of deaths, as Table 1.

With regard to BD percentage, ill all the hospitals the measurement was greater than $25 \%$, with an average of $27 \%$. The Hospital 1 (27.4\%) and the Hospital $3(28.6 \%)$ had the greatest percentage of $\mathrm{ME}$.

Of the total deaths in the three hospitals (321), 73\% ( $n$ 234) were due to cardiac arrest and $27 \%$ ( $n 87$ ) were BD. Of the BD identified, $74.7 \%$ ( $n$ 65) were notified to SCT's and $25.3 \%$ (n 22) were not validated as possible donors despite presenting all the criteria to start the ME diagnosis. It should be stressed that these were not notified to SCT's.

With respect to the notifications of potential donors to SCT's, Table 2, the Hospital 1 notified $27(41.5 \%)$ potential donors, followed by the Hospital 3 with $21(32.3 \%)$. With regard to the possible donors (not validated/underreported) the Hospital 3 was the one who more ceased to validate these possible donors $40.9 \%$ ( $n$ 09) cases.

With respect to the possible non-validated/underreported donors, in all the cases $25.3 \%$ ( $n$ 22) the cause of coma was defined, besides the presence of the aperceptive coma with Glasgow 3 scale, as described in Figure 1. In $95.5 \%$ (n 21) the fixed mydriasis was present and in $86.4 \%$ ( $n 19)$ no reflex of trunk was present. In $72.3 \%$ ( $n$ 17) the sedation was switched off for over 6 hours. In $72.3 \%$ of the cases there were clinical signs to start the BD protocol, considering the legislation in force. ${ }^{18-19}$

About the $25.3 \%$ (n 22) of the cases that have not been validated/underreported, the causes for not validating the clinical signs to start the BD protocol were not identified as hemodynamic alterations $78.3 \%$ ( $n 18$ ) and medical contraindications $21.7 \%$ (n 05).

With regard to the hemodynamic alterations, the Figure 2 shows that $33 \%$ ( $n$ 06) were related to hypotension, polyuria $28 \%$ ( $\mathrm{n} 05$ ), sodium greater than $155 \mathrm{mEq} / \mathrm{l} 22 \%$ (n 04) and temperature below $35.5^{\circ} \mathrm{C}$ in $17 \%$ ( $n$ 03).

With regard to the medical contraindications $21.7 \%$ ( $n$ 05) were identified for not validation, three were related to absolute

Table 1. General deaths and brain deaths identified in the units of critical patients in the three hospitals. FlorianópolisSC, 2018.

\begin{tabular}{lcccccc}
\hline \multirow{2}{*}{ Hospitals Variables } & \multicolumn{2}{c}{ Hospital 1 } & \multicolumn{2}{c}{ Hospital 2 } & \multicolumn{2}{c}{ Hospital 3 } \\
\cline { 2 - 6 } & $\mathrm{n}$ & $\%$ & $\mathrm{n}$ & $\%$ & $\mathrm{n}$ & 105 \\
\hline deaths for cardiac arrest & 124 & 100 & 92 & 100 & 23 & 100 \\
brain death\# & 34 & 27,4 & 23 & 25 & 30 & 28,6 \\
\hline
\end{tabular}

*deaths identified through the instrument

\#brain deaths identified when assessing the medical records from the instrument 
Table 2. Brain deaths identified in the three hospitals. Florianópolis-SC, 2018.

\begin{tabular}{|c|c|c|c|c|c|c|}
\hline \multirow{2}{*}{ Variables Hospitals } & \multicolumn{2}{|c|}{ Potential donors notified * } & \multicolumn{2}{|c|}{ Possible donors (not validated)\# } & \multicolumn{2}{|c|}{ Total of brain deaths } \\
\hline & $\mathrm{n}$ & $\%$ & $\mathrm{n}$ & $\%$ & $\mathrm{n}$ & $\%$ \\
\hline Hospital 1 & 27 & 41.5 & 07 & 31.8 & 34 & 39 \\
\hline Hospital 2 & 17 & 26.2 & 06 & 27.3 & 23 & 26.5 \\
\hline Hospital 3 & 21 & 32,3 & 09 & 40.9 & 30 & 34.5 \\
\hline Total & 65 & 100 & 22 & 100 & 87 & 100 \\
\hline
\end{tabular}

*Patients diagnosed with BD concluded and notified to State Central Transplantation

\#Patients with clinical criteria for the BD diagnosis, however they have not been identified/validated

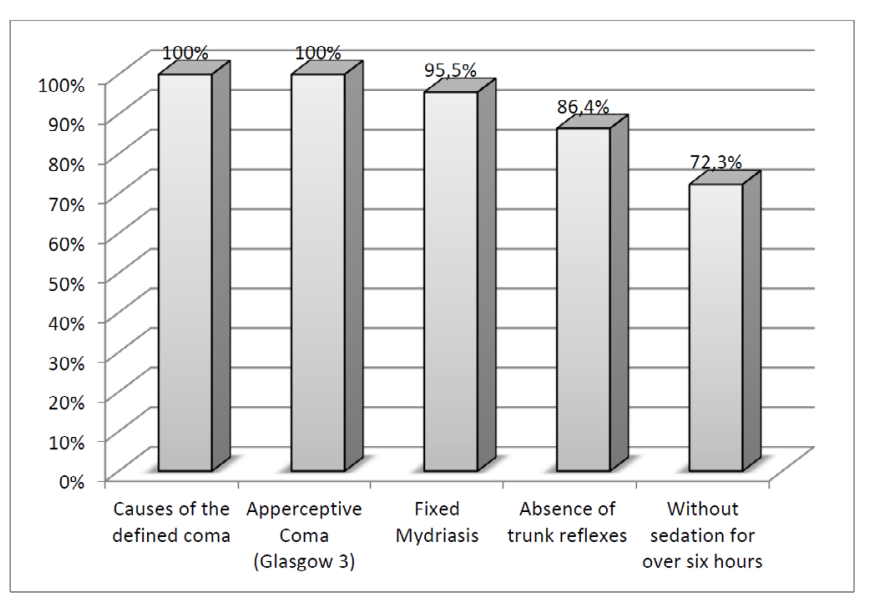

Figure 1. Distribution of the clinical signs of the possible brain deaths identified. Florianópolis-SC, 2018. Source: Data collected in this study.

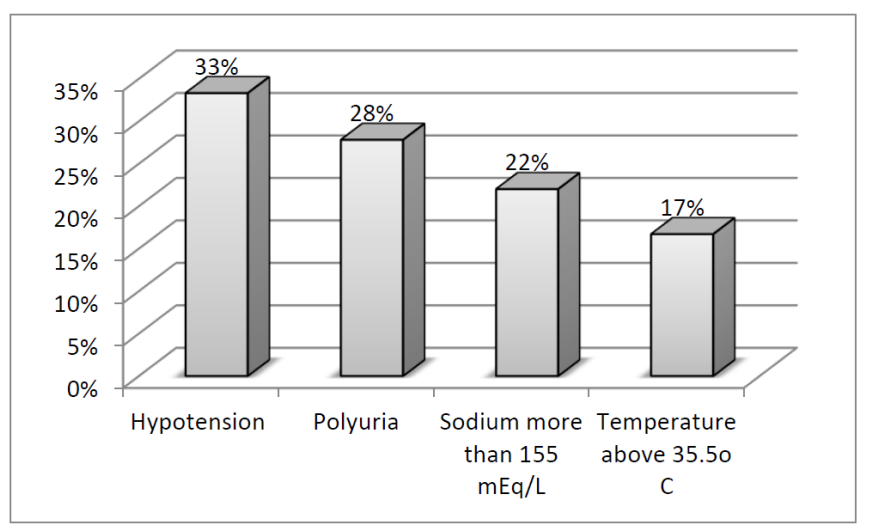

Figure 2. Distribution of the hemodynamic causes that made it impossible/ to validate the possible donor/ opening of the Brain Death protocol. Florianópolis-SC, 2018. Source: Data collected in this study.

contraindication due to the septic shock and two cases related to contraindication because of age.

\section{DISCUSSION}

In Brazil, there are few instruments used to support this professional to screen and monitor the development of each stage of this process. Currently, there are some indicators of results and process described in the current legislation. ${ }^{17-18}$ However, this same legislation defines for the HCT professionals the promotion of the quality, as well as the development of safe stages aimed at ensuring care to the bereaved family, agility in each stage of the process, as well as feasible organs for the transplantation. ${ }^{10-18}$

In the latter of the promotion of quality and safety in this process, the data of the current study indicate the possibility of screening and mapping possible donors, beyond of presenting opportunities of improvements when revealing the main causes of the non-validation of these potential donors to SCT's. It is still distinguished that in the three studied hospitals the BD porcentage was higher than $25 \%$, which value is higher than the one estimated in the legislation (14\%). ${ }^{18-19}$

The information about the exact number of $\mathrm{BD}$ is essential for the professionals working in the HCT. Since this diagnosis should be realized for all the patients with clinical signs, independent of having absolute or relative contraindication for organs donation and, considering that the notification of $\mathrm{BD}$ is of compulsory nature and is responsibility of the ICU's and HCT teams. However, the data show that there are still patients who cease to be validated as potential donor. This data may represent difficulties and insecurity of the ICUs'professionals to define the BD clinical criteria and conduct the BD diagnosis. Sudies ${ }^{20-21}$ show the insecurity and unpreparedness of the team to identify patients with $\mathrm{BD}$ clinical criteria, as well as how to conduct the BD protocol.

To screen and to chart information related to loss of patients with $\mathrm{BD}$ clinical criteria, besides the causes of the non-validation enables the health team, members of the HCT and nurses to elaborate permanent education strategies alongside the team of the critical patients units, as well as enables the development of guides, protocols and standard operating procedures, by ensuring safe and effective care and reducing the hemodynamical complications arisen from the clinical evolution of a BD.

The permanent education and the use of management tools in the organs and tissues donation process, as well as other activities developed by the health team, make it possible the improvement of the theoretical and scientific knowledge, changes of $i$ work process, qualification of the work, strenghtening of the workers, promotion of the improvement of the services organization, with effective results in the quality of care, in addition to generate 
changes and improvements in the processes and in the work relationships with team and family. ${ }^{21-26}$

In this perspective, the data of the study allow health professionals to develop permanent education and implementation of guidelines, protocols and other products that may support in an effective way in the management and care of the possible and potential organs donor,p since the study shows that the patients had criteria to start the diagnosis of BD when presenting apperceptive coma, fixed mydriasis and absence of trunk reflexes for over six hours. Studies point out that patients with serious brain lesions are more prone to change to the brain death.

Therefore, the team must perform an ongoing monitoring in front of the changes that may happen and within minutes, since phisiopathological alterations arisen from the neurological damage may cause the circulatory collapse and invalidate the conclusion of the ME $\mathrm{o}$ and the process of donation and transplant. ${ }^{27-28}$

It is worth highlighting that such alterations that cause the circulatory collapse in the patient under possible BD were identified in this study, since the patients presented hypernatremia hypotension, polyuria and hypotermia, the main causes of the nonvalidation/opening of the $\mathrm{BD}$ protocol. These conditions require from the professionals assistance, managerial and emotional efforts, being necessary the involvement of all the ICU's team, in order to make it possible hemodynamic conditions to start the BD protocol.

Studies point out that a series of hemodynamic changes occur in the BD, being necessary knowledge, agility and immediate action of the health team. Otherwise, it is possible that this patient may progress to cardiac arrest even before the validation as a possible donor or during the $\mathrm{BD}$ diagnosis confirmation. ${ }^{13}$ One of the great problems for opening of the BD protocol are the patient's hemodynamic conditions, being classified as "universal problems" ${ }^{3,27}$ of the transplantation ${ }^{27}$, such information met the data of the current study.

Face the loss of possible and potential donors, several countries such as Portugal, Holland, England, Germany and United States are improving the organs and tissues donation process, enabling opportunities of improvements based on actual information targeted to the diagnosis of the reality of each institution. The main actions of improvements realized in these countries include audits in the medical records in ICU's by identifying losses of possible, as well as the main causes of these losses. . $^{3-5,8-9,25-27,29-30}$ In addition, task forces of professionals seek adjustments in the system, in addition to education for improvements in this scenario.

The loss of possible donors and potential donors presented in this study, met the studies carried out in other countries, in which it is possible to identify loss of these patients related to hemodynamic questions, to the family refusal, in addition to the health team's frailty in conducting all the stages of this process. ${ }^{3,5,8-9,13,20}$ The need and the importance of the management and investigation of actual problems related to the loss of donors are pointed in the data of this study, since the hemodynamic stability was pointed as one of the main factors for not starting the BD clinical diagnosis. Hence, it becomes indispensable to investigate and screen such facts aiming at adjusting strategies of improvement designed to direct activities of training and preparation of the professionals to work in the ICU's about the BD criteria, BD diagnosis, maintenance of the possible donor, in addition to enable them with regard to the relative contraindications. Such actions have already been punctuated as effective in other studies. ${ }^{3,5,8-9}$

Based on the above considerations, the use of management tools is understood as essential to improve this process. Through them, there is the possibility to elaborate indicators of results and processes, which are able to measure data related to each stage of the donation process. Studies ${ }^{5,29}$ point out that the BD diagnosis, as well as the stages of the donation process need to be managed and evaluated.

In addition, the essential role of the nurse face the opportunities of improvements presented through the data of this study is understood, since the nursing team is the one who is directly involved in the care to the potential donor of organs and tissues. These are the professionals who conduct the care in the 24 hours and that manage any alteration related to hypotension, hypotermia, polyuria, hyponatremia, among others that may come out. It is worth noting that the causes of losses by hemodynamic alteration of the possible donors pointed in this study were related to hypotension, polyuria and hypotermia, these are factors that are achievable of being improved, in front of fast and effective actions becoming imperative care with tyhe purpose of providing the patient's hemodynamic stability an, consequently, the opening of the BD protocol. ${ }^{12,24,26}$

However, this team needs to be safe and able to care of this patient, since, when installing the $\mathrm{BD}$, there is no more any compensatory activity to help in maintaing the hemodynamic. Therefore, it becomes necessary an effective and fast performance of the health team to prevent the heart arrest and, thus, the loss of the possible donor. ${ }^{4,30}$

\section{CONCLUSION}

The hemodynamic instability and the contraindications are pointed as the main causes of losses of possible and potential donors of organs and tissues. With regard to the hemodynamic instability, it is s highlighting the hypotension, polyuria, hypernatremia and hypotermia. Regarding the opportunities of improvements in the organs and tissues donation system, it was pointed the actual measurement of the number of BD in each institution; porcentage of patients who ceased to be notified to SCT's, besides the causes that led the team not to start the BD protocol.

Through the information obtained, the health team may develop strategies directed at actual problems, occasioned in the stages of identification and validation of possible donors, health care to the potential donor, BD diagnosis, maintenance of the potential donor, as well as the causes of non-notification to SCT's. 


\section{FINANCIAL SUPPORT}

A scholarship of the Pro-Scholarships Program. Universidade Federal de Santa Catarina awarded to Juliana Santos. Two Scholarships of the Institutional Program of Scholarships of Scientific Initiation (PIBIC) of the Universidade Federal de Santa Catarina awarded to the Students Isabela dos Santos Wolter and Sibele Maria Schuantes Paim.

\section{REFERENCES}

1. Registro Brasileiro de Transplantes (RBT). Associação Brasileira de Transplantes de Órgãos (ABTO). Dimensionamento dos transplantes no Brasil e em cada estado. Associação Brasileira de Transplantes de Órgãos (ABTO). [Internet]; 2019. [cited 2019 May 24]. Available from http://www.abto.org.br/abtov03/Upload/file/RBT/2019/RBT-2019-1\%20 trim\%20-\%20Pop.pdf

2. Gois RSS, Galdino MJQ, Pissinati PSC, Pimentel RRS, Carvalho MDB, Haddad MCFL. Effectiveness of the organ donation process. Acta Paul Enferm [Internet] 2017 Nov/Dec; [cited 2019 Feb 26]; 30(6):6217. Available from: http://www.scielo.br/scielo.php?script=sci arttext\&pid=S0103-21002017000600621\&lng=en\&nrm=iso\&tlng=en. DOI: 10.1590/1982-0194201700089

3. Gatward JJ, O'Leary MJ, Sgorbini M, Phipps PR. Are potential organ donors missed on general wards? A 6-month audit of hospital deaths. Med J Aust [Internet] 2015; [cited 2019 Feb 26]; 202(4):205-8. Available from: https://www.mja.com.au/ journal/2015/202/4/are-potential-organ-donors-missed-general-wards6-month-audit-hospital-deaths. DOI: 10.5694/mja14.00316

4. Pilcher D, Gladkis L, Arcia B, Bailey M, Cook D, Cass Y, et al. Estimating the Number of Organ Donors in Australian Hospitals-Implications for Monitoring Organ Donation Practices. Transplantation [Internet] 2015 Oct; [cited 2019 Feb 26]; 99(10):2203-9. Available from: https://www.ncbi.nlm.nih.gov/pubmed/25919766. DOI: 10.1097/ TP.0000000000000716

5. White SL, Hirth R, Mahíllo B, Domínguez-Gil B, Delmonico FL, Noel $\mathrm{L}$, et al. The global diffusion of organ transplantation: trends, drivers and policy implications. Bull World Health Organ [Internet]. 2014 Nov; [cited 2019 Feb 26]; 92(11):826-35. Available from: https://www.ncbi. nlm.nih.gov/pmc/articles/PMC4221768/.DOI: 10.2471/BLT.14.137653

6. Knihs NS, Roza BA, Schirmer J, Ferraz AS. Application of Spanish quality instruments about organ donation and transplants validated in pilot hospitals in Santa Catarina. J Bras Nefrol [Internet]. 2015; [cited 2019 Feb 26]; 37(3)323-32. Available from: http://www.scielo.br/scielo. php?script=sci_abstract\&pid=S0101-28002015000300323\&Ing=en\& nrm=iso\&tlng=en. DOI: 10.5935/0101-2800.20150052

7. Ministerio de Sanidad, Consumo y Bienestar Social (ES). Plan Estratégico en Donación y Trasplante de Órganos 2018-2022: Sistema Español de Donación y Trasplante. Madrid: Ministerio de Sanidad, Consumo y Bienestar Social; 2018.

8. Tackmann E, Dettmer S. Measures influencing post-mortem organ donation rates in Germany, the Netherlands, Spain and the UK: A systematic review. Der Anaesthesist [Internet]. 2019 Jun; [cited 2019 May 24]; 68(6):377-83. Available from: https://link.springer.com/ article/10.1007\%2Fs00101-019-0600-4\#citeas. DOI: 10.1007/s00101019-0600-4

9. Hoste P, Ferdinante P, Hoste E, Vanhaecht K, Rogiers X, Eeckloo K, et al. Recommendations for further improvement of the deceased organ donation process in Belgium. Acta Clin Belgica [Internet]. 2016 Aug; [cited 2019 May 24]; 71(5):303-12. Available from: https://www. tandfonline.com/doi/citedby/10.1080/17843286.2016.1216259?scrol I=top\&needAccess=true. DOI: 10.1080/17843286.2016.1216259

10. Lomero MDM, Jiménez-Herrera MF, Rasero MJ, Sandiumenge A. Nurses' attitudes and knowledge regarding organ and tissue donation and transplantation in a provincial hospital: A descriptive and multivariate analysis. Nurs Health Sci [Internet]. 2017; [cited 2019 May 24]; 19(3):322-30. Available from: https://onlinelibrary.wiley.com/ doi/abs/10.1111/nhs.12348. DOI: https://doi.org/10.1111/nhs.12348

11. Magalhães ALP, Lanzoni GMM, Knihs NS, Silva EL, Erdmann AL. Patient safety in the process of organ and tissue donation and transplant. Cogitare Enferm [Internet]. 2017; [cited 2019 Feb 26]; 22(2):e45621. Available from: https://revistas.ufpr.br/cogitare/article/ view/45621/pdf_en. DOI: 0.5380/ce.v22i1.45621

12. Araújo C, Santos JAV, Rodrigues RAP, Guidi Júnior LR. O papel do profissional de enfermagem na doação de órgãos. Rev Saúde Foco [Internet]. 2017; [cited 2019 Feb 26]; 9:535-51. Available from: http://portal.unisepe.com.br/unifia/wp-content/uploads/ sites/10001/2018/06/061_papel_profissional_enfermagem.pdf

13. Istrate MG, Harrison TR, Valero R, Morgan SE, Páez G, Zhou Q, et al. Benefits of Transplant Procurement Management (TPM) specialized training on professional competence development and career evolutions of health care workers in organ donation and transplantation. Exp Clin Transplant [Internet]. 2015 Apr; [cited 2019 Feb 26]; 13(Suppl 1):148-55. Available from: https://www.ncbi.nlm.nih. gov/pubmed/25894145

14. Silva HB, Silva KF, Diaz CMG. Intensive nursing front of organ donation: an integrative review. Rev Pesq Cuid Fundam [Internet]. 2017 Jul/ Sep; [cited 2019 Feb 26]; 9(3):882-7. Available from: http://www. seer.unirio.br/index.php/cuidadofundamental/article/view/4514. DOI: 10.9789/2175-5361.2017.v9i3.882-887

15. Tolfo F, Camponogara S, Montesinos MJL, Siqueira $\mathrm{HCH}$, Scarton J, Beck CLC. The insertion of the nurse in intra-hospital commission of organ and tissue donation. Enferm Glob [Internet]. 2018 Apr; [cited 2019 Feb 26]; 17(50):185-223. Available from: http://scielo.isciii.es/ scielo.php?script=sci_arttext\&pid=S1695-61412018000200185\&Ing $=e n \& n r m=i s o \&$ tIng=en

16. O’Leary GM. Doação de órgãos de doador falecido: o papel da enfermeira de cuidados intensivos. Nursing Critical Care. 2018;13:2732.

17. Brasil. Decreto № 9.175 , de outubro de 2017. Regulamenta a Lei № 9.434, sancionada em 4 de fevereiro de 1997, para tratar da disposição de órgãos, tecidos, células e partes do corpo humano para fins de transplante e tratamento. Brasília (DF): Diário Oficial da União; 2017 [Internet]. [cited 2019 Feb 26]. Available from: https://presrepublica. jusbrasil.com.br/legislacao/511312696/decreto-9175-17

18. Ministério da Saúde (BR). Portaria №. 2.600, de 21 de outubro de 2009. Aprova o Regulamento Técnico do Sistema Nacional de Transplantes. Brasília (DF): Ministério da Saúde; 2009 [Internet]. [cited 2019 Feb 26]. Available from: http://www.ans.gov.br/images/ stories/Legislacao/camara_tecnica/2013_gt_revisao_rol/20130520doc12_contribconsnacdesauderegulamentotecnicodosnt.pdf

19. Brasil. Lei №.9.434, de fevereiro de 1997. Dispõe sobre a remoção de órgãos, tecidos e partes do corpo humano para fins de transplante, e dá outras providências. Brasília (DF): Diário Oficial da União; 1997 [Internet]. [cited 2019 Feb 26]. Available from: http://www.planalto.gov. br/ccivil 03/LEIS/L9434.htm

20. Foss S, Sanner M, Mathisen JR, Eide H. Doctors' attitudes to organ donation. Tidsskr Nor Laegeforen [Internet]. 2014 Jun; [cited 2019 Feb 26]; 134(11):1142-6. Available from: https://www.ncbi.nlm.nih.gov/ pubmed/24939780

21. Pestana AL, Erdmann AL, Sousa FGM. Emerging the complexity of nursing care facing a brain death. Esc Anna Nery [Internet] 2012 Oct/Dec; [cited 2019 Feb 26]; 16(4):734-40. Available from: http://www.scielo.br/scielo.php?script=sci_arttext\&pid=S1414$81452012000400013 \& \mathrm{Ing}=\mathrm{en}$. DOI: $10.1590 / \mathrm{S} 1414$ 81452012000400013

22. Fagherazzi V, Trecossi SPC, Oliveira RM, Souza JES, Sauer Neto $M$, Santos RP. Permanent education on organ/tissue donation with community health agents. J Nurs UFPE On Line (Recife) [Internet]. 2018 Apr; [cited 2019 Feb 26]; 12(4):1133-8. Available from: https:// periodicos.ufpe.br/revistas/revistaenfermagem/article/view/231367. DOI: 10.5205/1981-8963-v12i4a231367p1133-1138-2018

23. Silva KL, Matos JAV, França BD. The construction of permanent 
education in the process of health work in the state of Minas Gerais, Brazil. Esc Anna Nery [Internet] 2017 Aug; [cited 2019 Feb 26]; 21(4):e20170060. Available from: http://www.scielo.br/scielo. php?script=sci_arttext\&pid=S1414-81452017000400204\&lng=en. DOI: 10.1590/2177-9465-ean-2017-0060

24. Santos PS, Izaias PR, Silva SS, Brito TRP. A Atuação do Enfermeiro na Identificação e Manutenção do Potencial Doador de Órgãos e Tecidos que Esteja Sob Cuidados Intensivos. In: Annals of $16^{\circ}$ Congresso Nacional de Iniciação Científica. [Internet]; 2016 Nov 25-26; Guarulhos, SP, Brazil. Available from: http://conic-semesp.org.br/anais/files/2016/ trabalho-1000021523.pdf

25. Moraes RC, Cruz ICF. Evidence-based practice guidelines for the nursing intervention Cardiac care - acute phase in ICU: Systematic Literature Review. J Specialized Nurs Care [Internet]. 2018; [cited 2019 Feb 26]; 10(1). Available from: http://www.jsncare.uff.br/index.php/jsncare/article/ view/2975/754

26. Sales CB, Bernardes A, Gabriel CS, Brito MFP, Moura AA, Zanetti ACB. Standard Operational Protocols in professional nursing practice: use, weaknesses and potentialities. Rev Bras Enferm [Internet]. 2018 Jan; [cited 2019 Feb 26]; 71(1):126-34. Available from: http://www.scielo.br/scielo.php?script=sci_arttext\&pid=S003471672018000100126\&lng=en. DOI: 10.1590/0034-7167-2016-0621

25. Counter C, Murphy C. Potential Donor Audit - Summary Report for the 12 Month Period - 1 April 2010 - 31 March 2011. NHS Blood and Transplant [Internet] 2011; [cited 2019 Feb 26]; Available from: https://nhsbtdbe. blob.core.windows.net/umbraco-assets-corp/3179/pda_report_1011. pdf
26. Triassi M, Giancotti E, Nardone A, Mancini G, Rubba F. Organizational determinants in the procurement and transplantation pathway: a review. Transpl Res Risk Manag [Internet] 2015; [cited 2019 Feb 26] 7:1-12. Available from: https://www.dovepress.com/organizationaldeterminants-in-the-procurement-and-transplantation-pat-peerreviewed-article-TRRM. DOI: 10.2147/TRRM.S67467

27. Ludwing EFSB, Pereira MCA, Martinez YDE, Mendes KDS, Rossaneis MA. Prototype of a computerized scale for the active search for potential organ donors. Rev Lat Am Enferm [Internet]. 2017; [cited 2019 May 24]; 25:e2930. Available from: http://www.scielo.br/pdf/rlae/v25/0104-1169rlae-25-e2930.pdf. DOI: 10.1590/1518-8345.1936.2930

28. Humbertjean L, Mione G, Fay R, Durin L, Planel S, Lacour JC, et al. Predictive factors of brain death in severe stroke patients identified by organ procurement and transplant coordination in Lorrain, France. Transpl Int [Internet]. 2016 Mar; [cited 2019 May 24]; 29(3):299-306 Available from: https://onlinelibrary.wiley.com/doi/full/10.1111/tri.12695. DOI: 10.1111/tri.12695

29. Kocaay AF, Celik SU, Eker T, Oksuz NE, Akyol C, Tuzuner A. Brain Death and Organ Donation: Knowledge, Awareness, and Attitudes of Medical, Law, Divinity, Nursing, and Communication Students. Transplant Proc [Internet]. 2015 Jun; [cited 2019 Feb 26]; 47(5):1244-8. Available from: https://www.ncbi.nlm.nih.gov/pubmed/26093691. DOI: 10.1016/j. transproceed.2015.04.071

30. Correia WLB, Alencar SRM, Coutinho DTR, Gondim MM, Almeida PC, Freitas MC. Potential corpse donor: causes of non-organ donation. Enferm Foco [Internet]. 2018; [cited 2019 Feb 26]; 9(3):30-4. Available from: file:///C:/Users/susana/Downloads/1150-8143-1-PB.pdf. DOI: 10.21675/2357-707X.2018.v9.n3.1150 